University of Wollongong

Research Online

Faculty of Law, Humanities and the Arts Papers (Archive)

Faculty of Arts, Social Sciences \& Humanities

$1-1-2018$

Potter v. Minahan: Chinese Australians, the law and belonging in White Australia

Kate Bagnall

University of Wollongong, kbagnall@uow.edu.au

Follow this and additional works at: https://ro.uow.edu.au/lhapapers

Part of the Arts and Humanities Commons, and the Law Commons

Research Online is the open access institutional repository for the University of Wollongong. For further information contact the UOW Library: research-pubs@uow.edu.au 


\title{
Potter v. Minahan: Chinese Australians, the law and belonging in White Australia
}

\author{
Abstract \\ This article tells the story of James Minahan, the Melbourne-born son of a Chinese father and a white \\ Australian mother who was arrested as a prohibited immigrant under the Immigration Restriction Act in \\ 1908. Minahan had been taken to China by his father as a five-year-old boy in 1882 and failed the \\ Dictation Test on his return to Australia 26 years later. After Minahan defeated the charge in the lower \\ courts, the Commonwealth appealed to the High Court - an appeal they lost on the grounds that, despite \\ his years overseas, Minahan had remained a member of the Australian community. Although the case is \\ well known in historical and legal scholarship on Australian immigration and citizenship, existing work \\ has focused primarily on the High Court judgements. This article provides a new perspective by following \\ the progression of the case as a whole, from Minahan's return to Australia in January 1908 to the High \\ Court ruling in October that year, and placing it in the context of the transnational lives of Minahan, his \\ father and their fellow Chinese Australians. \\ Disciplines \\ Arts and Humanities | Law \\ Publication Details \\ Bagnall, K. (2018). Potter v. Minahan: Chinese Australians, the law and belonging in White Australia. \\ History Australia, 15 (3), 458-474.
}

This journal article is available at Research Online: https://ro.uow.edu.au/lhapapers/3628 


\title{
Potter v. Minahan: Chinese Australians, the law and belonging in White Australia
}

\author{
Kate Bagnall (iD \\ University of Wollongong, Australia
}

\begin{abstract}
This article tells the story of James Minahan, the Melbourne-born son of a Chinese father and a white Australian mother who was arrested as a prohibited immigrant under the Immigration Restriction Act in 1908. Minahan had been taken to China by his father as a five-year-old boy in 1882 and failed the Dictation Test on his return to Australia 26 years later. After Minahan defeated the charge in the lower courts, the Commonwealth appealed to the High Court - an appeal they lost on the grounds that, despite his years overseas, Minahan had remained a member of the Australian community. Although the case is well known in historical and legal scholarship on Australian immigration and citizenship, existing work has focused primarily on the High Court judgements. This article provides a new perspective by following the progression of the case as a whole, from Minahan's return to Australia in January 1908 to the High Court ruling in October that year, and placing it in the context of the transnational lives of Minahan, his father and their fellow Chinese Australians.
\end{abstract}

\section{KEYWORDS}

Migration; legal history; Chinese Australian history; White Australia Policy; Immigration Restriction Act

\section{Introduction}

In January 1908, James Minahan arrived in Australia after 26 years in China. Born in Melbourne in 1876, Minahan had been taken to China at the age of five by his father, Cheong Ming, a goldfields storekeeper. Growing up in his ancestral village in rural Kwangtung, Minahan came to remember little of the land of his birth or of his IrishAustralian mother, Winifred Minahan. Despite this, Australia was apparently always part of his father's plans for his future. Cheong Ming had kept a half share in his store at Indigo in north-eastern Victoria and planned that his son should eventually return there. However, as Minahan found out, in the new Australian nation such a right of return was not guaranteed if you were 'Chinese'. No longer able to speak the English of his Victorian childhood, Minahan was made to sit the Dictation Test, which he failed. Legal proceedings began, and after Minahan avoided deportation as a prohibited immigrant under the Immigration Restriction Act, his case proceeded to

CONTACT Kate Bagnall kate.bagnall@gmail.com

(C) 2018 Kate Bagnall

This is an Open Access article distributed under the terms of the Creative Commons Attribution License (http://creativecommons.org/ licenses/by/4.0/), which permits unrestricted use, distribution, and reproduction in any medium, provided the original work is properly cited. 
the High Court on appeal by the Commonwealth. In October 1908, the High Court found in Minahan's favour - by law, Australia was his home and he was free to remain.

The Minahan case garnered relatively little public attention in 1908, save for a handful of newspaper reports at pivotal moments during its progress through the courts. ${ }^{1}$ Yet the High Court decision in Potter v. Minahan has long been recognised for its significance in the history of Australian migration and citizenship law. It formed an important point of comparison for similar 'White Australia' cases in the early decades of the twentieth century, most notably the Donohoe v. Wong Sau case in 1925, and a century later it continues to be cited in High Court judgements. ${ }^{2}$ Potter v. Minahan has also been of interest to early commentators on Australian immigration law, to historians of the White Australia Policy and to contemporary legal scholars, who have focused particularly on its relevance to discussions of constitutional powers over immigration and citizenship. ${ }^{3}$

In this article I approach Potter v. Minahan from a different perspective. Using official Department of External Affairs and High Court records, I trace the progress of the administrative and legal case as a whole over the course of 1908, from James Minahan's arrival from Hong Kong on 23 January to the High Court's decision on 8 October. In doing so, I highlight the intricacies of the case as it moved between states and jurisdictions, and tease out the complex actions and interactions of Minahan, his supporters in the Chinese Australian community, government officials and the legal fraternity. ${ }^{4} \mathrm{I}$ thereby offer a more personal, as well as processual, history of law and belonging in White Australia, one that foregrounds the unfolding of decisions and their implications, in real time as it were, for the historical subjects involved. The Minahan case was one of nine immigration cases involving Chinese litigants heard in Australian appeal courts in the decade after the Immigration Restriction Act came into force, yet none of these

\footnotetext{
${ }^{1}$ A total of around 60 articles about the case appeared in Australian newspapers across February, April, September and October 1908, including in the Chinese-language Tung Wah Times. Many of the articles in regional newspapers were reprinted from the metropolitan dailies.

${ }^{2}$ On the Wong Sau case, see Donohoe v. Wong Sau [1925] HCA 6; 36 CLR 404. Another 1920s example is Robert Garran, Opinion No. 1279, 29 November 1922, AGS Legal Opinions (Canberra: Attorney-General's Department, n.d.), http://legalopinions.ags.gov.au/legalopinion/opinion-1279. For a recent High Court case, see Singh v. Commonwealth of Australia [2004] HCA 43; 222 CLR 322.

${ }^{3}$ See, for example, A. Berriedale Keith, 'The Legal Interpretation of the Constitution of the Commonwealth', Journal of the Society of Comparative Legislation 11, no. 2 (1911), 220-42; Everard Digby, 'Immigration Restriction in Australia', Journal of the Society of Comparative Legislation 12, no. 1 (1911): 81-84; A.T. Yarwood, Asian Migration to Australia: The Background to Exclusion 1896-1923 (Melbourne: Melbourne University Press, 1964); A.C. Palfreeman, The Administration of the White Australia Policy (Melbourne: Melbourne University Press, 1967); Paul Jones, 'Alien Acts: The White Australia Policy, 1901 to 1939' (PhD thesis, University of Melbourne, 1998); Kim Rubenstein, 'Citizenship and the Centenary - Inclusion and Exclusion in 20th Century Australia', Melbourne University Law Review 24, no. 3 (December 2000): 576-608; Mary Crock, 'Defining Strangers: Human Rights, Immigration and the Foundations of a Just Society', Melbourne University Law Review 31, no. 3 (2007): 1-19; Helen Irving, 'Still Call Australia Home: The Constitution and the Citizen's Right of Abode', Sydney Law Review 30, no. 1 (March 2008): 133-53; Sangeetha Pillai, 'Non-Immigrants, Non-Aliens and People of the Commonwealth: Australian Constitutional Citizenship Revisited', Monash University Law Review 39, no. 2 (2013): 568-609. Potter v. Minahan is also significant regarding the 'principle of legality'; see Brendan Lim, 'The Normativity of the Principle of Legality', Melbourne University Law Review 37 (2013): 372-414 (my thanks to Malcolm Oakes for bringing this point to my attention). ${ }^{4}$ The main sources used are: "Kitchen". Prohibited Immigrant', National Archives of Australia (hereafter NAA): A1, 1908/12936; 'POTTER Lionel Frank versus MINAHAN James Francis Kitchen', NAA: A10074, 1908/31; Potter v. Minahan [1908] HCA 63; 7 CLR 277, http://www.austlii.edu.au/au/cases/cth/HCA/1908/63/html.
} 
has yet been the focus of detailed historical study. ${ }^{5}$ Legal historian Mark Finnane has argued that such early Chinese-initiated cases deserve greater scrutiny because of their contribution to Australian law, illumination of the political dimensions of litigation, and potential to illustrate the strength of Chinese Australian community networks. ${ }^{6}$ In tracing the complexities of the Minahan case, I therefore aim to contribute to the small body of historical scholarship on Chinese litigation in Australia, particularly regarding the ways in which, in Finnane's words, 'Chinese immigrants and settlers were assertive in going to law to prosecute their own interests and defend their rights'. ${ }^{7}$ The law was one way in which Chinese Australians could challenge racialised policies of exclusion in colonial and postFederation Australia.

In tracing the progress of the Potter $v$. Minahan case, I further place it within the context of Minahan's own life in Australia and China to reveal something of the subjective experience of immigration law and policy, as well as the biases in its operation. Minahan's personal and familial circumstances carried substantial weight throughout the case; his parentage, legitimacy, upbringing and education all mattered because they factored into assessments of whether he was 'alien' or whether he could be counted as a member of the Australian community. ${ }^{8}$ As newspaper headlines from early 1908 put it, was James Minahan 'Citizen or alien?', 'Alien or native?', 'English or Chinese?', 'Australian or Asiatic'?' Minahan was not the only Chinese Australian to have a transnational childhood divided between Australia and China; many fathers like Cheong Ming wished for their Australian-born children, particularly sons, to be educated in Chinese language and customs and to retain a sense of their Chinese identity. ${ }^{10}$ The comings and goings of these children and families, and their mixed identities as Chinese and Australian, perplexed those policing the physical and cultural borders of White Australia. Work by Gwenda Tavan and others has shown how detailed exploration of immigration cases of the White Australia era offers the opportunity to consider the individuals and families at their centre, challenging 'the emphasis on "top-down" historical perspectives that have privileged the official public

\footnotetext{
${ }^{5}$ For a list of these cases, see Mark Finnane, 'Law as Politics: Chinese Litigants in Australian Colonial Courts', in Chinese Australians: Politics, Engagement and Resistance, ed. Sophie Couchman and Kate Bagnall (Leiden: Brill, 2015), 131-33.

${ }^{6}$ Ibid., 118.

"Ibid., 119. Other legal histories of Chinese in Australia include: Mark Finnane, "'Habeas Corpus Mongols" - Chinese Litigants and the Politics of Immigration in 1888', Australian Historical Studies 45, no. 2 (2014): 165-83; Heather Holst, 'Equal Before the Law? The Chinese in the Nineteenth-Century Castlemaine Police Courts', Journal of Australian Colonial History 6 (2004): 113-36; Jan Ryan, Ancestors: Chinese in Colonial Australia (South Fremantle: Fremantle Arts Centre Press, 1995), chapters 6 and 7; Alan Dwight, 'The Chinese in the NSW Law Courts, 1848-1854', Journal of the Royal Australian Historical Society 73, no. 2 (October 1987): 75-93.

${ }^{8}$ On the Chinese as perpetual 'aliens' in Australia, see Peter Prince, 'Aliens in Their Own Land: "Alien" and the Rule of Law in Colonial and Post-Federation Australia' (PhD thesis, Australian National University, 2015), chapter 2.

9'Citizen or Alien?', Daily Telegraph, 8 February 1908, 22, http://nla.gov.au/nla.news-article238098724; 'Alien or Native?', Advertiser, 8 February 1908, 11, http://nla.gov.au/nla.news-article5124640; 'English or Chinese?', Argus, 29 February 1908, 21, http://nla.gov.au/nla.news-article10666666; 'Australian or Asiatic', Advertiser, 1 April 1908, 6, http://nla.gov.au/nla.news-article5131017.

${ }^{10}$ See Janis Wilton, 'Chinese Voices, Australian Lives: Oral History and the Chinese Contribution to Glen Innes, Inverell, Tenterfield and Surrounding Districts during the First Half of the Twentieth Century' (PhD thesis, University of New England, 1996), chapter 9; and Kate Bagnall, 'Writing Home from China: Charles Allen's Transnational Childhood', in Migrant Lives: Australian Culture, Society and Identity, ed. Paul Longley Arthur (London: Anthem Press, 2018): 91-118. On the transnational overseas Chinese family, see Adam McKeown, 'Transnational Chinese Families and Chinese Exclusion, 1875-1943', Journal of American Ethnic History 18, no. 2 (1999): 73-110.
} 
story of the family over their subjective views and experiences'. ${ }^{11}$ Through such an approach, I would argue, we are also better placed to understand the uncertain pathways of non-Europeans, including Chinese Australians, within and without the boundaries of White Australia.

\section{Between Victoria and Sunwui}

James Francis Kitchen Minahan was born in Melbourne on 4 October 1876, the son of Cheong Ming and Winifred Minahan. Cheong Ming (陳象明) was from Shek Quey Lee (石渠里), a small village in Sunwui (新會) county in the southern Chinese province of Kwungtung (廣東). Cheong Ming had arrived in Victoria in the late 1850s or early 1860s, and a decade later was running a store at Indigo on the ChilternRutherglen goldfields in the north-east of the colony. There he lived with Melbourne native, Winifred Minahan, the eldest daughter of migrant Irish parents, born at Emerald Hill in February 1858. ${ }^{12}$ Winifred was much younger than Cheong Ming; she was only 17 when James was born in 1876, while Cheong Ming was in his forties. The couple were not married and their son's birth was registered under Winifred's surname only, with no details recorded of Cheong Ming as his father. ${ }^{13}$

James Minahan spent the first five years of his life with his parents at Indigo, in the Chinese goldmining village of Mount Pleasant on the Indigo Lead north of Chiltern. $^{14}$ In June 1881, he was joined by a baby sister, Winifred Leina Chong Meng. ${ }^{15}$ Tragically, baby Winifred died at the age of three months and within a year the family had separated. ${ }^{16}$ Suffering from a bad leg, Cheong Ming returned to China, taking young James with him, while Winifred remained in Victoria. ${ }^{17}$ Before leaving Indigo in the middle months of 1882, Cheong Ming put his business in the care of Chin Shing, who had worked for him for six years, and gave him a half share in the Indigo store. Over the years that followed, father and son maintained contact with Chin Shing, but Winifred disappeared completely from James's life. After he left Melbourne, he never saw his mother again.

From Melbourne, father and son travelled to Cheong Ming's home village, Shek Quey Lee, via Hong Kong and the river port town of Kongmoon (江門). Shek Quey Lee was home to families of the surname Chan (陳), and many men from this and

\footnotetext{
${ }^{11}$ Gwenda Tavan, '"Poor Little Nancy": The Nancy Prasad Case and the Commonwealth Immigration Department', Australian Historical Studies 44, no. 2 (2013): 244. See also Sean Brawley, 'Finding Home in White Australia', History Australia 11, no. 1 (April 2014): 128-48; Margaret Allen, "'Most Painful and Humiliating": The Surveillance of Sher Mohamad', Studies in Western Australian History 28 (2013): 69-83; and Kel Robertson, Jessie Hohmann and lain Stewart, 'Dictating to One of Us: The Migration of Mrs. Freer', Macquarie Law Journal 5 (2005): 241-75.

${ }^{12}$ Victorian Registry of Births, Deaths and Marriages (hereafter VIC BDM), Winefred Managyan (birth), 1858/609; VIC BDM, Richard Monaghan and Mary Mangan (marriage), 1856/3602; VIC BDM, Catherine Minahan (birth), 1865/9864.

${ }^{13}$ The birth registration of their second child stated that Cheong Ming and Winifred Minahan were married in Melbourne in September 1873, but there is no other evidence this was the case. No marriage registration has been located. VIC BDM, James Francis Kitchen Minahan (birth), 1876/21528; VIC BDM, Winifred Cheong Meng (birth), $1881 / 15146$.

${ }^{14}$ On Chinese at Indigo, see Nell Begley and Rex Fuge, ed., Cornishtown and Prentice Freehold Reunion 1873-1998 (Chiltern, Vic: R. Fuge, 1998).

${ }^{15}$ VIC BDM, Winifred Cheong Meng (birth), 1881/15146.

${ }^{16}$ VIC BDM, Winifred Chong Meng (death), 1881/6963.

${ }^{17}$ My narrative of James Minahan's life in Sunwui is based on testimonies to the Court of Petty Sessions, Melbourne, in March 1908. See Copy Documents (prepared by Charles Powers), NAA: A10074, 1908/31.
} 
nearby villages had gone to Victoria over the preceding decades, returning home to visit when their circumstances allowed. ${ }^{18}$ In Shek Quey Lee, Cheong Ming became a schoolmaster and young James began his education in Chinese. James became known by his Chinese name, Ying Coon (英群), and in time forgot the English he had spoken as a boy in Indigo. After more than a decade in the village, in the mid-1890s Cheong Ming died. James was then in his late teens. He later recalled that his father had not planned for their stay in China to be a long one: 'He said he would stay a little time in China, and then go back to Australia', but ill health had prevented him from doing so. ${ }^{19}$

According to James Minahan, before his death Cheong Ming had talked to his son about Australia and their business interests there, and had shown him his birth certificate, which was kept in a box in their home. ${ }^{20}$ Cheong Ming encouraged his son to study hard and gain a degree, saying that he could then return to Australia and make good money teaching the sons of fellow Chinese. After they had returned to China, Chin Shing had sent them regular remittances from the business at Indigo and these were enough to support James after his father's death, enabling him to continue with his studies. At the age of 23 he attended the gruelling Imperial examinations, but failed this and two subsequent attempts. After his third failure, and the abolition of the Imperial examination system after 1905, he decided to return to Australia.

In late 1907, James wrote to Chin Shing asking him to send money for his passage. Chin Shing sent him $£ 21$ via Sun Nam Hie \& Co. (新南泰) in Little Bourke Street, Melbourne. They then sent the money to the firm of Quong Hing Yeong in Hong Kong, who assisted James with preparations for his trip. The SS Taiyuan was due to sail from Hong Kong for Sydney on 1 January 1908, and so James left Shek Quey Lee, his home for 26 years, on the first stage of his journey to Melbourne, the city of his birth. ${ }^{21}$ At Quong Hing Yeong he paid HK\$210 to book his passage on the Taiyuan and presented his birth certificate as proof of his right to land in Australia. Shipping companies were liable for penalties under the Immigration Restriction Act if they knowingly carried 'prohibited immigrants' to Australia, and hence required proof when tickets were purchased. ${ }^{22}$ In such circumstances it was common for Australian-born Chinese to use their birth certificates to demonstrate their right of entry and domicile in Australia as native-born British subjects, a practice that carried over from the earlier colonial period. ${ }^{23}$ British subject-status was granted to every child born on Australian soil (jus soli, or birthright citizenship), regardless of their parents' race or nationality.

\footnotetext{
${ }^{18}$ On Shek Quey Lee's Australian connections, see Kate Bagnall, 'Landscapes of Memory and Forgetting: Indigo and Shek Quey Lee', Chinese Southern Diaspora Studies 6 (July 2013): 7-24, http://chl-old.anu.edu.au/publications/csds/ csds2013/csds2013_04.pdf.

${ }^{19}$ Evidence of James Francis Kitchen Minahan, 28 February and 31 March 1908, Copy Documents (prepared by Charles Powers), 13-16, NAA: A10074, 1908/31.

${ }^{20}$ lbid., 15.

${ }^{21}$ 'Vessels Advertised as Loading', China Mail (Hong Kong), 31 December 1907, 8.

${ }^{22}$ Immigration Restriction Acts 1901-1905 (Cth), ss 9 and 13.

${ }^{23}$ On the use of birth certificates, see Kate Bagnall, 'Anglo-Chinese and the Politics of Overseas Travel from New South Wales, 1898 to 1925', in Couchman and Bagnall, Chinese Australians, 212-18.
} 


\section{An unexpected welcome}

James Minahan was one of 39 Chinese passengers who arrived in Sydney on the Taiyuan on 23 January 1908, but his name, as such, did not appear on the passenger manifest. Instead, he was listed as James Kitchen, aged 31, storekeeper. His race was given as 'Chinese' and, under the column for nationality, it was noted that he had a birth certificate, no. 23003. Sydney Customs Inspector J.T.T. Donohoe was on the wharf to meet the Taiyuan and, after inspecting the passengers' papers, decided to give Minahan the Dictation Test. This was the passage he read:

A large part of the cheapening of steel has been brought about by this one device for using cheap inferior fuels. In the iron trade it was discovered many years ago that it paid to produce more of this particular gas than could be used in the purely metallurgical operations. ${ }^{24}$

Minahan was unable to complete the test, but as his ultimate destination was Melbourne, not Sydney, he was allowed to continue on with five fellow Chinese passengers. They were handprinted and trans-shipped to the SS Wollowra, and sailed for Melbourne on 24 January.

Donohoe forwarded their handprints and documents, including the birth certificate, to assist Melbourne Customs with the men's identification. After the Wollowra arrived on 26 January, the six men were briefly seen by Customs Officer Hugh Mercer. However, as it was a Sunday and Mercer had no Chinese interpreter with him, he decided to return the following day to formally examine them. Mercer returned on Monday and, with the help of government translator Harry Hoyling, interviewed Minahan in the ship's saloon. Mercer also spoke to 'a reputable Chinaman', tobacco dealer Chan Num, who had known Minahan as a boy and had come to meet him at the wharf. Ching Kay of Sun Nam Hie in Little Bourke Street, another Shek Quey Lee native, also met the boat.

To execute his duties under the Immigration Restriction Act, Mercer needed to establish whether the birth certificate Minahan presented was really his own. He later noted that there was no indication on the certificate that it belonged to someone who was 'Chinese'. It was in the name 'James Francis Kitchen', and listed only the baby's mother, 'Winifred Minahan'. Alert to the possibilities of fraud, Mercer suspected that the certificate did not legitimately belong to this man, who seemed Chinese in appearance and manner and who understood not a word of English. After interviewing Minahan, Mercer was not convinced and so applied the Dictation Test. Through the interpreter, Harry Hoyling, Mercer told Minahan that he was going to read a passage of not less than 50 words in English and that he was required to write them in English. He gave Minahan a pencil and paper and read a passage once slowly. It was the same passage Donohoe had read in Sydney. When asked, Minahan said that he could not write out the passage. Mercer informed him that he was a prohibited immigrant and that he could not land in Australia. Consequently, Minahan was to be transferred back to the Taiyuan in Sydney and then returned to Hong Kong. He was not at this point formally charged under the Immigration Restriction Act.

\footnotetext{
${ }^{24}$ Copy of Dictation Test from 16 to 31 January 1908, NAA: A1, 1908/12936.
} 
The next day, Minahan left Melbourne for Sydney on the Wollowra, and Melbourne Customs informed their Sydney colleagues of his rejection under the Immigration Restriction Act. When he arrived in Sydney, Minahan was escorted by Inspector Donohoe back to the Taiyuan, which was due to sail for Hong Kong at the end of the following week. On 6 February, however, two days before the scheduled departure, the Taiyuan's master, Captain Lancelot Dawson, was asked to show cause why a writ of habeas corpus should not be issued against him for holding Minahan on board. Habeas corpus - asking a court to decide on the lawfulness of a person's detention - was a tactic long used by Chinese Australians to secure the release of those held on board ship who were facing deportation as prohibited immigrants. ${ }^{25}$ Only seven months earlier, for example, it had been used successfully in the case of a youth named Willie Lee Hook, whose situation was very similar to that of James Minahan. ${ }^{26}$

The case against Captain Dawson was heard by Justice Philip Street of the Supreme Court in chambers on 7 February. Barrister F.S. Boyce acted on Minahan's behalf in the matter, under instruction from Deane and Deane Solicitors as agents for Croft and Rhoden Solicitors of Melbourne. ${ }^{27}$ Boyce argued that as a natural-born British subject Minahan was entitled to enter the Commonwealth, and he presented affidavits from Minahan and several Chinese residents of Victoria attesting to the facts of Minahan's Victorian birth and subsequent travel to China with his father. Captain Dawson argued that he was acting on the orders of a Commonwealth Customs officer, who had declared that Minahan was a prohibited immigrant, noting that under section 9 of the Immigration Restriction Act the master of a vessel was liable for a penalty of $£ 100$ if a prohibited immigrant landed from his vessel. On hearing the evidence, Justice Street ruled in Minahan's favour, concluding that neither Captain Dawson nor the Commonwealth had demonstrated that Minahan was a prohibited immigrant under the Act. Justice Street therefore ordered Minahan's release.

Minahan left the Taiyuan at around one o'clock that afternoon, but he was not free for long. Acting on instructions from the Department of External Affairs, Inspector Donohoe had waited at Circular Quay and arrested Minahan as he left the wharf. He was formally charged with being a 'prohibited immigrant found within the Commonwealth in contravention of the Immigration Restriction Act, 1901-1905'. ${ }^{28}$ Minahan was brought before the Water Police Court at two o'clock on Friday, 7 February, and was remanded in custody until the following Friday. He was held in Darlinghurst Gaol.

When Minahan was rejected at Melbourne, solicitor E.A. Fortescue Croft, of Croft and Rhoden Solicitors in Melbourne, had rushed to Sydney to start legal proceedings on his behalf. Although there is no certain evidence in the archives, it is likely that it was Minahan's uncles in Melbourne, Ah Doe and Ah Yuey, who organised and paid for this legal representation. Another possibility is that it was done through the

\footnotetext{
${ }^{25}$ See Finnane, 'Habeas Corpus Mongols'.

26،Prohibited Immigrant', Argus, 12 July 1907, 4, http://nla.gov.au/nla.news-article10142694; 'One Month's Grace', Argus, 13 July 1907, 19, http://nla.gov.au/nla.news-article10155422; 'Habeas Proceedings re WILLIE LEE HOOK', NAA: A5522, M47.

${ }^{27}$ 'Is He an Australian?', Evening News, 7 February 1908, 6 and 7, http://nla.gov.au/nla.news-article114098110.

${ }^{28}$ Statement by J.T.T. Donohoe, 10 February 1908, NAA: A1, 1908/12936.
} 
auspices of the Kong Chew Society (岡州會館) or the See Yup Society (四邑會館), welfare and mutual aid societies established in Melbourne in the 1850s for people from Sunwui county and the See Yup or Four Counties district, of which Sunwui was a part. ${ }^{29}$ Croft was a sensible choice of solicitor, as he already had experience in representing Chinese Australians in their legal struggles against the Commonwealth and continued to do so in the years that followed. ${ }^{30}$ The financial and logistical support of his uncles and others in the Chinese community was critical to Minahan's ability to challenge the charge against him, as he did not have the necessary language skills or cultural capital to navigate the system alone.

After the arrest in Sydney, Croft requested that Minahan's case be transferred to Melbourne, where his client had greater resources and contacts. By an agreement reached with the Crown Solicitor, the Sydney charges against Minahan were to be dropped and he would be arrested again on his arrival in Melbourne. Minahan was released from Darlinghurst Gaol on 11 February and left that night on the express train for Melbourne, where he was duly arrested by Constable Lionel Potter of the Victorian Police. The new charge against Minahan was:

being an immigrant who within one year after he had entered the Commonwealth failed to pass the dictation test within the meaning of the Immigration Restriction Acts 1901-1905 and being a prohibited immigrant was found within the Commonwealth in contravention of the said Immigration Restriction Acts 1901-1905 of the Commonwealth of Australia. ${ }^{31}$

Minahan was taken to the watch house and the following day his matter was heard at the City Court. Croft asked for an adjournment so he could call witnesses. He was allowed two weeks and a new hearing date was set for 28 February. Minahan was allowed out on bail of $£ 100$, and after his release he went to stay at Sun Nam Hie in Little Bourke Street, which was owned by his uncles, Ah Doe and Ah Yuey.

\section{The right to return?}

The parties reassembled on 28 February, when the matter was heard in the Court of Petty Sessions before Police Magistrate Charles Creswell. The Crown Solicitor had advised Atlee Hunt that 'good Counsel' should be nominated to prosecute the Commonwealth's case, and the man they chose, H.W. Bryant, was a prominent Melbourne barrister, later a King's Counsel, who was known to be 'a brilliant advocate and skillful cross-examiner'; he was also Edmund Barton's nephew. ${ }^{32}$ Minahan's barrister, W.T. Coldham, was equally accomplished. ${ }^{33}$ Detailed records of the

\footnotetext{
${ }^{29}$ On the Kong Chew Society and See Yup Society, see C.F. Yong, The New Gold Mountain: The Chinese in Australia 1901-1921 (Richmond, SA: Raphael Arts, 1977), 189-93.

${ }^{30} \mathrm{Croft}$ and Rhoden had represented Willie Lee Hook in a similar case in 1907: 'Prohibited Immigrant', Argus, 12 July 1907, 4, http://nla.gov.au/nla.news-article10142694. See also, for example, 'The Chinese Exclusion Law', Age, 29 September 1911, 9, http://nla.gov.au/nla.news-article196210126 (case of Lim Wee); 'Chinese or Australian?', Weekly Times, 25 October 1913, 33, http://nla.gov.au/nla.news-article222611116 (case of Suey Land).

${ }^{31}$ Information for an Offence in the Court of Petty Sessions, Melbourne, 14 February 1908, NAA: A10074, 1908/31.

${ }^{32}$ Crown Solicitor to Atlee Hunt, Secretary, Department of External Affairs, 8 February 1908, NAA: A1, 1908/12936; 'Died at His Post', Geelong Advertiser, 25 October 1924, 1, http://nla.gov.au/nla.news-article2115594931924; 'Death of Mr. Bryant, K.C.', Argus, 25 October 1924, 32, http://nla.gov.au/nla.news-article2056772.

${ }^{33}$ 'Death of Mr. W. T. Coldham', Leader, 6 June 1908, 34, http://nla.gov.au/nla.news-article 198110745.
} 
proceedings were taken down by a clerk from the Crown Solicitor's office, John Gardner Davies, and his notes provide the remaining record of the evidence given at this lower court hearing, including evidence given by Minahan and other witnesses. ${ }^{34}$

The Commonwealth's case was that Minahan was a prohibited immigrant within the meaning of the Immigration Restriction Act. To their minds, Minahan had provided no satisfactory evidence of his identity and so, having failed the Dictation Test, he was a prohibited immigrant. In response, Minahan's lawyers argued that he was a 'native of Victoria' and that his domicile, which had not permanently changed during his time in China, remained in Victoria. He could not therefore be a 'prohibited immigrant' because someone domiciled in Victoria could not be considered an 'immigrant'. For the prosecution, evidence was heard from Customs Officer Hugh Mercer and translator Harry Hoyling, as well as Detective Lionel Potter, who had arrested Minahan in Melbourne. For the defence, Minahan's solicitor gathered together a number of witnesses to give evidence as to Minahan's identity and his Australian birth. One potential witness who did not appear was Minahan's mother, Winifred; he had lost contact with her and believed that she had died in Melbourne some years before. ${ }^{35}$ White mothers could be instrumental in securing the re-admission of children on their return from an extended stay in China, providing a concrete tie to their European heritage, Australian birth and British nationality. ${ }^{36}$ In Minahan's case, evidence of these ties came in a different form.

Minahan's witnesses, many of whom were from the same village of Shek Quey Lee, were men who knew him and his father in Victoria and Sunwui. One, for example, was Ching Kay (陳象都), who had owned the Hang Yick store in Little Bourke Street until 1906, after which time he worked at Sun Nam Hie. His AngloChinese wife, Ethel née Hun Gip, was a cousin of translator Harry Hoyling. ${ }^{37}$ Ching Kay had a house opposite Cheong Ming's in Shek Quey Lee and had seen father and son daily during three extended visits he made to the village during the 1880s and 1890s. It was also through Ching Kay that Chin Shing had sent money from the Indigo store. Ching Kay had seen young James and his father when they went off to China in 1882, and he was certain this adult James Minahan was that boy: 'When he arrived I saw him standing on board the ship when I was on the wharf ... I had no doubt about him'. ${ }^{38}$ The other men who gave evidence were Chin Shing, Deung Garng (a French polisher in Melbourne), Ah Chew (a cabinet maker in Carlton), Dern Hoy (another French polisher in Melbourne), Chan Num (a tobacco dealer in South Melbourne, formerly of Beechworth) and Ah Doe (Minahan's uncle and

\footnotetext{
${ }^{34}$ The following description of the Court of Petty Sessions hearing is based on information provided in Davies' notes. See Affidavit of John Gardner Davies, 22 April 1908, Copy Documents (prepared by Charles Powers), NAA: A10074, $1908 / 31$.

${ }^{35}$ 'Citizen or Alien?', Daily Telegraph, 8 February 1908, 22, http://nla.gov.au/nla.news-article238098724. The only certain trace of Winifred Minahan I have located after her son went to China is a record of her marriage to a Japanese man named Arai Arai in Melbourne in 1886; VIC BDM, Arai Arai and Winifred Minahan (marriage), $1886 / 6985$.

${ }^{36}$ See Bagnall, 'Anglo-Chinese and the Politics of Overseas Travel'.

${ }^{37}$ Hoyling also had family connections to Minahan's barrister in the High Court, William Ah Ket, and Ah Ket later represented Hoyling when he was charged with conspiracy in 1913. See Bagnall, 'Landscapes of Memory and Forgetting', 18, and 'Conspiracy Charge', Argus, 27 November 1913, 12, http://nla.gov.au/nla.news-article7287323.

${ }^{38}$ Evidence of Ching Kay, 28 February 1908, Copy Documents (prepared by Charles Powers), 9, NAA: A10074, $1908 / 31$.
} 
co-owner of Sun Nam Hie). This collective testimony provided the link between the baby named in the birth certificate and the grown man who stood before the court. The men's enduring personal and familial connections with Cheong Ming and James Minahan, over the course of three decades and in two countries, were the best evidence Minahan had of his Australian birth.

Minahan's own testimony began on 28 February 1908. It was not complete when court rose for the day, and various adjournments meant that it was a full month until he was able to continue. The case resumed in court on $31 \mathrm{March}$, at which time Minahan faced further questions from his own counsel and then a cross-examination from Bryant. Minahan spoke in Chinese, presumably in the Sunwui variant of See Yup Cantonese spoken in Shek Quey Lee, and Hoyling translated his testimony. ${ }^{39}$ Hoyling's background was not dissimilar from Minahan's, being born in Victoria in 1878 to a white Australian mother and a Chinese father and spending eight years in China from the age of $13 .{ }^{40}$ Hoyling's Chinese home was in the See Yup county of Toishan, where they spoke a similar dialect to Sunwui. ${ }^{41}$

Central to the case was Minahan's place of birth, and Bryant asked him about the Victorian birth certificate he had presented as his own in Sydney. Minahan told the magistrate that although he had kept the certificate safely for many years, he was unable to read what it said. He did, however, read to the court the words in Chinese written on the back, which in translation were: 'James Francis Kitchen, Ying Coon, original is lost, (Chinese date), 31'. Hoyling translated the text when he appeared for the prosecution, and his version read: 'English name, James Francis Kitchen. Also Chinese date. This is a duplicate copy, the original has been lost'. Minahan told the court that his father had kept the certificate at home and had shown it to him when he was about 15 or 16, at which time Cheong Ming had written the words on the back. The certificate had been issued and certified in Melbourne on 10 July 1882, a date that tallied with the departure of young James and his father from Victoria, but the prosecution's questioning showed they believed it had been acquired for the purpose of effecting fraudulent entry to Australia. From the 1880s, when anti-Chinese immigration laws were reintroduced in Victoria and New South Wales, officials had grown increasingly suspicious of Chinese using birth and naturalisation certificates as proof of Australian domicile and right of re-entry, believing there to be a widespread trade in these identity documents among the Chinese in Australia, Hong Kong and the emigrant districts in south China. ${ }^{42}$

The rest of Minahan's evidence centred on the fact that he, and his father before him, had planned to return to Australia. Minahan firmly believed that his original

\footnotetext{
${ }^{39}$ On Chinese interpreters in the Victorian courts, see Nadia Rhook, "'The Chief Chinese Interpreter" Charles Hodges: Mapping the Aurality of Race and Governance in Colonial Melbourne', Postcolonial Studies 18, no. 1 (2015): 1-18.

${ }^{40}$ Jon Kehrer, 'Honourable Ancestors: My Search for the Chinese Connection' The Ancestral Searcher 27, no. 4 (December 2004), 328-33.

${ }^{41}$ On Sunwui dialect and its relationships to Toishan dialect, see James Dyer Ball, 'The San-Wúí (新會) Dialect', China Review 18, no. 3 (November-December 1889): 178-95.

${ }^{42}$ Bagnall, 'Anglo-Chinese and the Politics of Overseas Travel', 211-12. Colonial anti-Chinese immigration laws included exemptions for returning residents; some resident Chinese were granted special certificates or letters of exemption, but many relied on naturalisation and birth certificates to facilitate re-entry. Following the introduction of the Immigration Restriction Act, resident Chinese usually travelled using Certificates of Domicile (to 1905) or Certificates Exempting from the Dictation Test, but naturalisation and birth certificates could still be used as evidence of Australian domicile.
} 
home was in Victoria, even though he could remember little of it. He had only a 'faint recollection' of his mother, 'an English woman' who was 'not very stout', but he did remember her seeing them off at the wharf. Of his new life in Sunwui, he recalled that 'people about called me the little foreign devil boy', including his schoolmates, and that he cried when his father shaved his head according to local custom. Minahan further described his education in the village, his attempts at the Imperial examinations, his father's illness and death, and his ongoing interaction and correspondence with men he knew in Victoria.

With the end of Minahan's testimony, the case for the defence was finished and proceedings drew to a close. Police Magistrate Creswell reserved his judgement until the following Thursday, 2 April, at which time he found that it had been proved that Minahan's domicile had not changed from Victoria, that he was not an immigrant and therefore not subject to the Immigration Restriction Act. Creswell was convinced by the evidence presented by the defence as to Minahan's identity, his early life in Australia and his intention to return to Australia at some future time, concluding: 'In leaving Victoria for China the father in the first instance and afterwards his son, the defendant, did not intend to permanently change the domicile of defendant from Victoria to China'. ${ }^{43}$ The case was dismissed, with costs of $£ 10$ 10s to go to the defendant.

As the case had progressed, the Crown Solicitor, Charles Powers, kept Robert Garran, Secretary of the Attorney-General's Department, and Atlee Hunt, Secretary of the Department of External Affairs, abreast of developments. He forwarded them both a copy of the Police Magistrate's judgement and asked for instructions on whether it was intended to appeal 'on the question of law as to whether in the circumstances he is an immigrant within the meaning of the Immigration Restriction Act'. ${ }^{44}$ Hunt went to Garran for advice, and Garran, with the approval of AttorneyGeneral Littleton Groom, recommended that the Commonwealth should proceed with an appeal. Hunt told the Crown Solicitor on 10 April that 'the Prime Minister directs that the decision be appealed from'. ${ }^{45}$ The Commonwealth wanted a clear ruling from the High Court about who, by law, could and could not be considered an 'immigrant'.

\section{Potter v. Minahan}

A number of earlier cases had begun to clarify the meaning of terms used in the Immigration Restriction Act, including the seemingly fundamental one of who could be considered an 'immigrant'. The government was reliant on the courts to provide such clarification because the Constitution did not include the concept of 'Australian citizen'; until the passing of the Australian Citizenship Act in 1948, residents of Australia were either British subjects or aliens. As Kim Rubenstein has noted, one reason for the absence of a definition of Australian citizenship in the Constitution

\footnotetext{
${ }^{43}$ Affidavit of John Gardner Davies, 22 April 1908, Copy Documents (prepared by Charles Powers), 17, NAA: A10074, 1908/31, 17-18.

${ }^{44}$ Ibid.

${ }^{45}$ Annotated Minute Paper from the Attorney-General's Department, 8 April 1908, NAA: A1, 1908/12936.
} 
was the desire of its drafters to exclude non-whites; it was simpler to leave the concept of Australian citizenship vague and undefined than deal with the question of Chinese and Indians, in particular, who had come from other British colonies and held British nationality. ${ }^{46}$

In 1905, the High Court had ruled that an immigrant was simply someone who entered the Commonwealth, whether they were planning to stay a short or long time. ${ }^{47}$ However, a year later, the High Court upheld a decision from the Supreme Court of Victoria that Ah Sheung, a naturalised British subject who had left his home in Victoria for a temporary visit overseas, did not fall under the terms of the Act when he entered the Commonwealth. ${ }^{48}$ In that case, Chief Justice of the High Court Samuel Griffith noted that:

We think there is much force in the view ... although not argued before us, that the term 'immigration' does not extend to the case of Australians - to use for the moment a neutral word - who are merely absent from Australia on a visit animo revertendi [with the intention of returning]. ${ }^{49}$

Concurrent with the Ah Sheung case, Prime Minister Alfred Deakin had asked for advice from the Attorney-General on the question of whether being born in Australia prevented someone, on returning to Australia after a lengthy absence, from being considered an 'immigrant' within the meaning of the Immigration Restriction Act. The request cited the fact that there were at that time a number of cases before the Department of External Affairs of Australian-born Chinese returning from overseas claiming that 'by reason of their having been born here, they are entitled to exemption'. ${ }^{50}$ The Attorney-General, Littleton Groom, offered the opinion that an Australian birth was not conclusive one way or the other (there being no explicit constitutional right of entry to Australia if you were an Australian-born British subject), and Groom argued that the facts in each individual case would need to be reviewed. ${ }^{51}$ Minahan's case was, therefore, one of dozens of cases over the following decades in which the differing personal and familial circumstances of Chinese and part-Chinese Australians were central to how they were treated in the operation of the law.

With the definition of 'immigration' still uncertain in 1908, the Minahan case provided the High Court with an opportunity to provide further clarity. Justice Isaac Isaacs heard the Commonwealth's application for review of the Police Magistrate's decision on 28 April and permitted the appeal to proceed. The Commonwealth's appeal was on the grounds that Minahan was prima facie an immigrant, and furthermore a prohibited immigrant, within the meaning of the Immigration Restriction Act; that the findings of fact by the Police Magistrate were against the weight of

\footnotetext{
${ }^{46}$ Rubenstein, 'Citizenship and the Centenary', 580. See also Kim Rubenstein, Australian Citizenship Law, 2nd ed. (Sydney: Thomson Reuters, 2017), 50-52.

${ }^{47}$ Chia Gee v. Martin (1905) 3 CLR 649.

${ }^{48}$ Attorney-General for the Commonwealth v. Ah Sheung (1907) 4 CLR 949.

${ }^{49}$ Chief Justice Samuel Griffith, quoted in 'Ah Sheung - Immigration Restriction Act', Minute Paper by Robert Garran, Secretary, Attorney-General's Department, 28 November 1906, NAA: A1, 1908/1498.

50'Application of Immigration Restriction Act 1901-05 to Australian-Born Chinese', Minute Paper by Atlee Hunt, Secretary, Department of External Affairs, 6 October 1906, NAA: A1, 1906/8578.

${ }^{51}$ 'Immigration Restriction Acts 1901-5 - Persons Born in Australia', Minute Paper by Littleton Groom, AttorneyGeneral, 27 November 1906, NAA: A1, 1906/8578.
} 
evidence; and that there was no evidence that Cheong Ming (spelled 'Teung Ming' in the court papers) or James Minahan were domiciled in Australia.

Charles Power, the Crown Solicitor, noted in a letter to Atlee Hunt that the 'principal reason for [the High Court] granting the Order appeared to be that the question had been before the Court in Ah Sheung's case and left undecided' ${ }^{52}$ Two of the justices of the High Court who would hear the Minahan case, Edmund Barton and Richard O'Connor, had been members of the Australian Parliament that passed the original version of the Immigration Restriction Act in 1901, and all five justices had been involved in the drafting of the Constitution through the 1890s federal conventions. ${ }^{53}$ They strictly interpreted the law within the political and legal contexts of its creation, guided by the principle that, in the words of historian Paul Jones, 'as the Parliament had particular intentions in mind when framing legislation, the Court should not adopt interpretations ... which would clearly make an absurdity of these intentions. ${ }^{54}$

Although the Commonwealth's appeal in the Minahan case was initially listed for the High Court's May sittings, it was not heard until 16 September 1908. It was heard before the Full Bench of the High Court - Chief Justice Samuel Griffith, and Justices Edmund Barton, Richard Edward O’Connor, Isaac Isaacs and Henry Bourne Higgins. H.W. Bryant again appeared for the Commonwealth, while Minahan was represented by Frank Gavan Duffy KC, one of the best trial lawyers of the time and later Chief Justice of the High Court, along with William Ah Ket, a young Chinese Australian barrister. Ah Ket, born in rural Victoria in the same year as Minahan, was Australia's first Chinese barrister, qualifying in 1902, and an active champion of the legal and political rights of Chinese Australians. ${ }^{55}$ The hearing continued for three days, and the judgement was finally delivered on 8 October. Each justice gave a separate ruling and, although not unanimous in their reasoning, they agreed that the appeal should be dismissed. The order of the Police Magistrate was upheld and the High Court declared that Minahan was not a prohibited immigrant. He was free to remain in Australia.

The High Court justices saw there were two parts to the case. The first, whether Minahan could be called an immigrant under the Immigration Restriction Act, consumed most of the justices' attention as they were keen to set their opinions down on record. The second, which in the words of Griffith was of 'comparatively little importance', was whether Minahan had actually failed the Dictation Test as set out in the Act. Certainly, he had not written the passage as was required of him

\footnotetext{
${ }^{52}$ Charles Power, Crown Solicitor, to Atlee Hunt, Secretary of the Department of External Affairs, 30 April 1908, NAA: A1, 1908/12936.

${ }^{53}$ My thanks to Peter Prince for bringing this point about Barton and O'Connor to my attention. On the drafting of the Constitution, see Nicholas Aroney, The Constitution of a Federal Commonwealth: The Making and Meaning of the Australian Constitution (Cambridge: Cambridge University Press, 2008).

${ }^{54}$ Jones, 'Alien Acts', 98.

55،A Chinese Barrister', Leader, 29 November 1902, 36, http://nla.gov.au/nla.news-article196580331; John Lack, 'Ah Ket, William (1876-1936)', Australian Dictionary of Biography (Canberra: Australian National University, 1979), http:// adb.anu.edu.au/biography/ah-ket-william-4979/text8267.
} 
under the Act, but had Customs Officer Hugh Mercer actually applied the test properly? ${ }^{56}$

On the question of whether Minahan was an immigrant, Chief Justice Samuel Griffith first considered the meaning of the term. Counsel for the Commonwealth had put it that within section 51 of the Constitution, immigration referred to every person entering Australia, an argument rejected by Griffith, who stated that it meant more than 'mere physical entry into the Commonwealth'. There was no doubt that Minahan had entered the Commonwealth, and that he had come from China, but did the facts of the case support the argument that he was an 'immigrant'? The Police Magistrate had presumed that Minahan's parents were married and that he was legitimate, but Griffith made no such presumption: 'Having regard to the conditions in Victoria in 1876, and to the relations between Chinese and European women at that time, I think that there is not even a prima facie probability of a legal marriage'. ${ }^{57}$ This was further supported by the fact that Minahan's birth was registered without providing his father's name. Griffith thus reasoned that at birth Minahan had acquired both British nationality and his mother's domicile of Victoria, and that in the intervening years he had never voluntarily chosen a different domicile. If Minahan's birth had been legitimate, it could perhaps have been reasoned that his domicile, or even nationality, followed that of his father when they had gone to live in China. Griffith felt that the immigration question could not be determined by 'the mere application of the rules of either nationality or of domicil [sic]'. There was something more at play, for the concepts of nationality and domicile were both founded on

an elementary part of the concept of human society, namely, the division of human beings into communities. From this it follows that every person becomes at birth a member of the community into which he is born, and is entitled to remain in it until excluded by some competent authority. ${ }^{58}$

Minahan was entitled 'by the circumstances of his birth' to regard Victoria as his home. For Griffith, Minahan was not an immigrant, but had retained his membership of the Australian community.

Like Griffith, Barton accepted the evidence presented to the Police Magistrate. Creswell had the opportunity to observe the demeanour of those who gave evidence, and had 'an experience in weighing the evidence of Chinese which is denied to those who merely read their written or printed depositions'. The magistrate had 'not been able to detect ... a tissue of fabrications woven by conspiracy; he believes its truth, and says so'. Barton also questioned the magistrate's presumption of Minahan's legitimacy and doubted that his parents had married, for there was 'nothing to show that their relations differed from those which have been so common between Chinese and European women'. He arrived at the same conclusion as Griffith, too, that Minahan's domicile of origin was the same as his mother's and, as he had not voluntarily chosen any other, so it remained. The question of 'home' was, for Barton, also relevant. He concluded that Minahan

\footnotetext{
${ }^{56}$ The following discussion of the High Court judgement is based on Potter v. Minahan [1908] HCA 63; 7 CLR 277, http://www.austlii.edu.au/au/cases/cth/HCA/1908/63/html.

${ }^{57}$ Potter v. Minahan [1908] HCA 63; 7 CLR 277.

${ }^{58}$ Ibid.
} 
had not made China his home. Victoria was his old home. His return to it was the fulfilment of an oft-expressed desire and intention. Was his return a home-coming? I cannot refuse to say that it was. When he was taken away in 1882 he was a member of this community, and here lay his home. He did not make himself a fresh one in another community. He is entitled to this one. ${ }^{59}$

For Barton, Minahan could not be considered an immigrant.

O'Connor saw that there were two parts to the question of whether Minahan was an immigrant: what was the definition of 'immigrant' in section 3 of the Act, and had the evidence established that he was an immigrant within that definition? After consulting four dictionaries as to the common meaning of 'immigration', and considering case law on questions of domicile and nationality, O'Connor concluded that 'a person cannot be an immigrant into the country which is his home'. But was Australia Minahan's home? The critical point for O'Connor in coming to the conclusion that it indeed was, was once again the circumstances of Minahan's birth. As the illegitimate Victorian-born son of a British-subject mother, O'Connor found that Minahan was not an immigrant.

For Isaacs, 'immigration' connoted two facts - that there was entry into the Commonwealth and that the person entering was not, at that moment, one of the people of the Commonwealth. If a person could not demonstrate that they were 'a portion of the people of the Commonwealth, as an ordinary reasonable person would understand the matter', he was an immigrant. If he then failed the Dictation Test, he was a prohibited immigrant. Isaacs saw that while in China, Minahan had not prepared himself 'in the smallest degree for life in the country, he now would have us believe, he unceasingly treasured in his heart for 26 years as his real and unabandoned home'. While in China, Isaacs stated, 'He was in language, education, ideas, and probably religious faith, entirely at one with the people around him; every day found him closer to them, and farther from the people of Australia'. ${ }^{60}$ In a sense, then, he was not 'transnational' enough. Isaacs concluded that Minahan was not one of the people of the Commonwealth; he had not retained Australia as his permanent home, becoming instead identified with the people of China and the locality where he had lived for so long. He was therefore an immigrant.

In the final decision, Higgins set himself the following question to answer: 'Was the respondent's residence or habitat in China before he left China to come to Australia?' If so, he was an immigrant. Higgins distinguished the idea of residence from the legal constructs of domicile and nationality, stressing that the words of the Act should be interpreted by their ordinary meaning. Higgins saw that Minahan's residence or his home, in the ordinary sense of the word, over the previous decade and a half (since his father's death) had been in China. Being born in Australia did not change that, nor did it mean that the Act could not apply to him, hence Higgins found that Minahan was an immigrant.

Three of the five justices - Griffith, Barton and O'Connor - therefore agreed that Minahan was not an immigrant under the Immigration Restriction Act. Griffith and Barton did not express an opinion on the further question before them, of whether

\footnotetext{
${ }^{59}$ Ibid.

${ }^{60}$ Ibid.
} 
the Dictation Test had been applied properly. For Isaacs and Higgins, however, who found that Minahan was an immigrant, it was only on this second point of the case that they found grounds to dismiss the appeal. Together with O'Connor, they found that Customs Officer Hugh Mercer had not given the Dictation Test to Minahan in accordance with what was required under the Act, and therefore that Minahan could not be a prohibited immigrant. The appeal was already overturned on the question of whether Minahan was an immigrant or not, but Mercer's procedural mishandling was not to be viewed as an insignificant matter. A circular issued to Customs officers in April 1909 admonished them to carefully note the justices' findings and 'act strictly in accordance with the requirements of the Act' ${ }^{61}$

It is unclear exactly what James Minahan was doing during the months it took for his case to be heard before the High Court, but he certainly remained in Melbourne, presumably living at Sun Nam Hie in Little Bourke Street. After his testimony before the Court of Petty Sessions at the end of March 1908, the only record of his doings is in the bill of costs prepared by his solicitor, which notes that Minahan and an interpreter met with Croft on two occasions in May. Minahan was awarded costs by the High Court - the legal fees for his appeal amounted to $£ 1256 \mathrm{~s}$, and he was also entitled to $£ 10$ 10s awarded in the lower court hearing, coming to a total of $£ 13516 \mathrm{~s}$. With the payment of these costs and some administrative tidying up, the case of Potter v. Minahan ended. So, it would seem, does any trace of James Minahan. He was free to remain in Australia, but despite extensive searching, in the archives and on the ground in Australia and Sunwui, I have not yet ascertained if Minahan stayed in the country of his birth or returned to China once again.

\section{Conclusion}

Armed with his birth certificate and secure in the knowledge that he had both friends and financial resources in Victoria, James Minahan could hardly have imagined that his return to Australia would proceed as it did. In his court testimony he said that he had 'always wanted to return to Australia' and that his father had told him this was possible; indeed, it should have been his right as a British subject born in the colony of Victoria. However, over the years of Minahan's absence, a time when the Australian colonies were moving towards Federation, the politics of the white nation had come into being and there were new laws, policies and administrative hurdles to leap. Being born in Australia was not enough to guarantee a right of return if you were 'Chinese'.

The transnational lives of Chinese Australians like James Minahan, his father and their fellow Shek Quey Lee villagers challenged the limits of belonging in White Australia. Over half a century these men had forged ongoing connections between Sunwui and Victoria, connections that prompted the movement of generation after generation to and fro across increasingly solid colonial, and then national, borders. These men saw that they had a continuing place in Australia - indeed, many had businesses, homes and families there - and at the border and in the courts they

\footnotetext{
${ }^{61}$ Circular by the Collector of Customs, Customs and Excise Office, Port Adelaide, 8 April 1909, NAA: D596,
} $1909 / 2128$. 
vigorously tested decisions of the state that suggested otherwise. The archives are replete with records that document these negotiations; in particular, thousands of official case files, like James Minahan's, through which the manoeuvres of both Chinese Australians and government officials can be traced and analysed.

The story of the Minahan case as I have told it suggests how we might be attentive, in writing legal and administrative histories based on such records, to the effects of law and policy on individual and family lives and, conversely, the effects of individual lives on law and policy. When we look closely, stories like James Minahan's show us the negotiated nature of the Immigration Restriction Act - and, more broadly, the White Australia Policy - revealing its unfolding, living history and its ongoing effects. Such stories also show us Chinese Australians in the making of Australian law. Through their presence and their actions, the boundaries of belonging were defined and refined, in terms of both exclusion and inclusion. Investigating the ways in which Chinese Australians interacted with the law can therefore bring us closer to understanding the complicated meanings of legal, racial and cultural belonging in White Australia.

\section{Disclosure statement}

No potential conflict of interest was reported by the author.

\section{About the author}

Dr Kate Bagnall is an ARC DECRA Research Fellow in the School of Humanities and Social Inquiry at the University of Wollongong, where she is working on a comparative study of Chinese colonial citizenship in Australia, Canada and New Zealand. She has published on various aspects of Chinese Australian history and is co-editor, with Sophie Couchman, of Chinese Australians: Politics, Engagement and Resistance (Brill, 2015). Much of her research explores the lives of the women, children and families of Australia's early Chinese communities and the transnational connections and qiaoxiang ties of Chinese Australians before 1940.

\section{Funding}

This article was produced with the support of the National Archives of Australia (Ian Maclean Award 2012-2013), the Australian Academy of the Humanities (Travelling Fellowship 2014) and the Australian Research Council (DECRA DE160100027).

\section{ORCID}

Kate Bagnall (D) http://orcid.org/0000-0003-1426-7294 